chance finding. The results suggest that the risk of childhood cancer in the vicinity of these power lines is not a major public health concern. The relation between a risk of childhood cancer and exceptionally high levels of residential exposure to magnetic fields should not, however, be inferred from this study.

Imatran Voima Oy funded this study. We thank the many people who participated in collecting the data and in calculating the magnetic fields, particularly $\mathrm{Mr}$ Martti Korpiranta of VTKK Computing Services Ltd. We gratefully acknowledge Dr Jaakko Kaprio and Dr Lyly Teppo, who commented on the final report.

1 Wertheimer $\mathrm{N}$, Leeper E. Electrical wiring configurations and childhood cancer. Am f Epidemiol 1979;109:273-84.

2 Tomenius $\mathrm{L} .50-\mathrm{Hz}$ electromagnetic environment and the incidence of childhood tumors in Stockholm county. Bioelectromagnetics 1986;7:191-207.

Savitz DA, Wachtel H, Barnes FA, John EM, Tvdrik JG. Case-control study of childhood cancer and exposure to $60-\mathrm{Hz}$ magnetic fields. $\mathrm{Am} \mathcal{F}$ Epidemiol 1988;128:21-38.

4 Olsen JH, Nielsen A, Schulgen G. Residence near high voltage facilities and risk of cancer in children. $B M 7$ 1993:307:891-5.

5 Myers A, Clayden AD, Cartwright RA, Cartwright SC. Childhood cancer and overhead powerlines: a case-control study. Br f Cancer 1990;62:1008-14

6 Feychting M, Ahlbom A. Magnetic fields and cancer in people residing near Swedish high voltage power lines. Stockholm: Insitutet för miljömedicin, Karolinska insitutet, 1992. (IMM publication No 6/92.)

7 London SJ, Thomas DC, Bowman JD, Sobel E, Cheng TC, Peters JM.
Exposure to residential electric and magnetic fields and risk of childhood leukaemia. Am J Epidemiol 1991;134:923-37.

8 Fulton JP, Cobb S, Preble L, Leone L, Forman E. Electrical wiring configurations and childhood leukemia in Rhode Island. Am $\mathrm{f}$ Epidemiol 1980;111:292-6.

9 Valjus J, Hongisto M, Järvinen P, Verkasalo P, Heikkilä K, Koskenvuo $M$ The exposure estimation method of the Finnish cohort study of cancer an Thesure to magetic fields. In: Blank $M$, ed. Eloctricity and magnetion in exposure to magnetic fields. In. Blank $\mathrm{M}$, ed. Electricity and magnetisn

10 National Agency for Welfare and Health. Cancer Incidence in Finland 1989 and 1990. Helsinki: Cancer Society of Finland, 1992. (Publication No 51.)

11 American Cancer Society. Manual of tumor nomenclature coding. Atlanta: American Cancer Society, 1951 .

12 Doll R. Electromagnetic fields and the risk of cancer. Repon of an advisory group on non-ionising radiation. Chilton, Didcot, Oxon: National Radiological Protection Board, 1992:35-53. (Documents of the NRPB, vol 3; No 1.)

13 Juutilainen J, Saali K, Eskelinen J, Matilainen P, Leinonen AL. Measurements of $50 \mathrm{~Hz}$ magnetic fields in Finnish homes. Helsinki: Imatran Voima Oy, 1989. (Imatran Voima Oy research reports, 2/89.)

14 Juutilainen J, Läärä E, Pukkala E. Incidence of leukaemia and brain tumours in Finnish workers exposed to ELF magnetic fields. Int Arch Occup Environ Health 1990;62:289-93.

15 Floderus B, Persson T, Stenlund C, Linder G, Johansson C, Kiviranta J, et al. Occupational exposure to electromagnetic fields in relation to leukemia and brain tumors. A case-control study. Stockholm, Sweden: Litohuset, 1992

$16 \mathrm{Li}$ FP. Cancers in children. In: Schottenfeld D, Fraumeni J, eds. Cancer epidemiology and prevention. Philadelphia: Saunders, 1982:1012-24.

17 Higginson J, Muir CS, Muños N. Human cancer: epidemiology and environmental causes. Cambridge: Cambridge University Press, 1992:479-92.

18 Wertheimer N, Leeper E. Re: Electrical wiring configurations and childhood leukemia in Rhode Island. Am f Epidemiol 1980;111:461-2.

(Accepted 10 September 1993)

\title{
Arthroscopic surgery compared with supervised exercises in patients with rotator cuff disease (stage II impingement syndrome)
}

\author{
Jens Ivar Brox, Peer H Staff, Anne Elisabeth Ljunggren, John Ivar Brevik
}

\section{Abstract}

Objective-To compare the effectiveness of arthroscopic surgery, a supervised exercise regimen, and placebo soft laser treatment in patients with rotator cuff disease (stage II impingement syndrome).

Design-Randomised clinical trial.

Setting-Hospital departments of orthopaedics and of physical medicine and rehabilitation.

Patients-125 patients aged 18-66 who had had rotator cuff disease for at least three months and whose condition was resistant to treatment.

Interventions-Arthroscopic subacromial decompression performed by two experienced surgeons; exercise regimen over three to six months supervised by one experienced physiotherapist; or 12 sessions of detuned soft laser treatment over six weeks.

Main outcome measures-Change in the overall Neer shoulder score (pain during previous week and blinded evaluation of function and range of movement by one clinician) after six months.

Results-No differences were found between the three groups in duration of sick leave and daily intake of analgesics. After six months the difference in improvement in overall Neer score between surgery and supervised exercises was 4.0 (95\% confidence interval -2 to 11$)$ and $2.0(-1.4$ to 5.4$)$ after adjustment for sex. The condition improved significantly compared with placebo in both groups given the active treatments. Treatment costs were higher for those given surgery $(£ 720 v £ 390)$.

Conclusions-Surgery or a supervised exercise regimen significantly, and equally, improved rotator cuff disease compared with placebo.

\section{Introduction}

Pain in the shoulder is a common medical problem. Its prevalence was $14 \%$ in a Swedish epidemiological study. ${ }^{1}$ Work or leisure activities that entail raising the arms or working with hand tools increase the risk of developing shoulder pain. ${ }^{2-5}$ The prevalence of supraspinous tendinitis was $18 \%$ among welders.

Ischaemia, inflammation, and degeneration are related to age and overload of the tendons of the short rotator muscles and are present in rotator cuff disease. ${ }^{6-8}$ Impingement of the cuff and the subacromial bursa on elevation increases the pain and may contribute to long term changes. Rotator cuff disease or the impingement syndrome is classified according to its progression: acute inflammation (tendinitis or bursitis) (stage I); degeneration or chronic inflammation, ${ }^{7}$ or both (stage II); rupture and arthritis (stage III). ${ }^{9}$

Commonly, rest, analgesics, anti-inflammatory drugs, local steroid injections, and remobilisation with simple exercises will resolve most cases of tendinitis. ${ }^{10}$ The results of the long term outcome of these treatments, however, is not promising, ${ }^{11}$ although open anterior and arthroscopic acromionplasty have a success rate of $80-90 \% .{ }^{12-14}$ We compared arthroscopic subacromial decompression and supervised exercises in a controlled, randomised series of patients with rotator cuff disease. To our knowledge, such a study has not been published before.

\section{Subjects and methods}

SELECTION OF PATIENTS

General practitioners serving a population of half a million were invited to refer patients with rotator cuff disease.

Patients were included if they were aged 18-66; had had pain in the shoulder for at least three months that had been resistant to outpatient physiotherapy and non-steroid and steroid anti-inflammatory drugs; had dysfunction or pain on abduction; had a normal passive glenohumeral range of movement; had pain during two of the three isometric-eccentric tests (abduction at $0^{\circ}$ and $30^{\circ}$ and external rotation) ${ }^{15}$; and had positive results in tests for impingement. ${ }^{9}$ Lignocaine $(6 \mathrm{ml}$; $10 \mathrm{mg} / \mathrm{ml}$ ) was injected anteriorly into the subacromial space. ${ }^{15}$ The diagnosis was confirmed if pain was
Correspondence to:

Dr Brox.

BMF 1993;307:899-903 
appreciably reduced on re-examination after 15 minutes.

Patients were excluded if they had arthritis of the acromioclavicular joint; had the cervical syndrome; had rotator cuff rupture; had glenohumeral instability; had bilateral muscular pain with tenderness and severely decreased ability to relax the shoulder, neck, and temporomandibular joints on examination; and were reluctant to accept one or more of the treatment regimens of the study.

All eligible patients were informed about the three treatments: arthroscopic surgery, supervised exercise regimen, or detuned laser (placebo). They were told that the placebo option was a new type of laser treatment. Treatments were allocated by the method of random permuted blocks. The ethics committee for medical research in health region I of Norway approved the study.

Of the total of 444 patients referred, 125 agreed to participate and gave their informed, signed consent (figure).

\section{TREATMENTS}

In Norway patients usually have to wait for six months to two years for elective arthroscopic surgery to the shoulder. The average time between randomisation and the first day of treatment in this study was two months in all groups.

Two experienced orthopaedic surgeons at Menighetssøsterhjemmets Hospital performed the arthroscopic surgery. The aim of the procedure is to make better space for the rotator cuff to reduce the risk of impingement. Standard treatment consisted of bursectomy and resection of the anterior and lateral

TABLE I-Reasons why treatment varied from that originally allocated. Values are numbers of patients

\begin{tabular}{|c|c|c|c|}
\hline \multirow[b]{2}{*}{ Reason } & \multicolumn{3}{|c|}{ Original allocation to: } \\
\hline & $\begin{array}{l}\text { Arthroscopic } \\
\text { surgery } \\
(n=13)\end{array}$ & $\begin{array}{l}\text { Placebo } \\
\text { laser } \\
(n=4)\end{array}$ & $\begin{array}{l}\text { Supervised } \\
\text { exercises } \\
(n=7)\end{array}$ \\
\hline Diagnosis changed & 3 & 1 & 1 \\
\hline Adhesive capsulitis & 1 & 1 & 1 \\
\hline Muscular pain & 1 & & \\
\hline Synovial chondromatosis & 1 & & \\
\hline Condition improved & 3 & & 1 \\
\hline Did not attend for follow up & 4 & & \\
\hline Lack of motivation & & & 4 \\
\hline Operated on & & 2 & $1^{\star}$ \\
\hline Had exercises & 3 & 1 & \\
\hline
\end{tabular}

^Did not attend for follow up.

TABLE II-Baseline characteristics of study population according to treatment group. Values are numbers (percentages) of patients unless stated otherwise

\begin{tabular}{|c|c|c|c|c|c|c|}
\hline & \multicolumn{2}{|c|}{ Arthroscopic surgery } & \multicolumn{2}{|c|}{ Placebo laser } & \multicolumn{2}{|c|}{ Supervised exercises } \\
\hline & $\begin{array}{c}\text { Intention } \\
\text { to treat } \\
(n=45)\end{array}$ & $\begin{array}{c}\text { Treatment } \\
\text { different } \\
(n=13)\end{array}$ & $\begin{array}{c}\text { Intention } \\
\text { to treat } \\
(n=30)\end{array}$ & $\begin{array}{c}\text { Treatment } \\
\text { different } \\
(n=4)\end{array}$ & $\begin{array}{c}\text { Intention } \\
\text { to treat } \\
(\mathrm{n}=50)\end{array}$ & $\begin{array}{c}\text { Treatment } \\
\text { different } \\
(\mathrm{n}=8)\end{array}$ \\
\hline Mean age (years) & 48 & 54 & 48 & 47 & 47 & 44 \\
\hline Women & $16(36)$ & $5(39)$ & $15(50)$ & $4(100)$ & $28(56)$ & $3(38)$ \\
\hline \multicolumn{7}{|l|}{ Duration of complaint: } \\
\hline$<6$ months & $8(18)$ & $5(39)$ & $5(17)$ & $1(25)$ & $6(12)$ & $2(25)$ \\
\hline 6 months- 1 year & $8(18)$ & $1(8)$ & $5(17)$ & & $6(12)$ & \\
\hline $1-3$ years & $9(20)$ & $1(8)$ & $5(17)$ & $1(25)$ & $13(26)$ & $4(50)$ \\
\hline$>3$ years & $20(44)$ & $6(46)$ & $14(48)$ & $2(50)$ & $25(50)$ & $2(25)$ \\
\hline Bilateral pain & $11(24)$ & $4(31)$ & $7(23)$ & $1(25)$ & $12(24)$ & (38) \\
\hline Dominant arm affected & $28(62)$ & $9(69)$ & $16(53)$ & $3(75)$ & $31(62)$ & $6(75)$ \\
\hline Shoulder pain affected by work & $36(80)$ & $11(85)$ & $24(79)$ & $4(100)$ & $41(81)$ & $7(88)$ \\
\hline \multicolumn{7}{|l|}{ Sickness leave: } \\
\hline Currently taken & $27(60)$ & $9(71)$ & $18(60)$ & $3(75)$ & $27(54)$ & $6(75)$ \\
\hline Median duration (months) & $4 \cdot 6$ & $4 \cdot 3$ & $4 \cdot 1$ & $3 \cdot 3$ & $4 \cdot 5$ & $5 \cdot 1$ \\
\hline \multicolumn{7}{|l|}{ Receiving pension from work on } \\
\hline grounds of incapacity & $2(4)$ & 0 & $9(3)$ & 0 & $3(5)$ & 0 \\
\hline \multicolumn{7}{|l|}{ Unable to participate in previous } \\
\hline leisure activities & $28(62)$ & $9(71)$ & $11(37)$ & $2(50)$ & $27(54)$ & $4(50)$ \\
\hline Taking analgesics & $30(67)$ & $8(62)$ & $23(75)$ & $3(75)$ & $39(77)$ & $3(38)$ \\
\hline \multicolumn{7}{|l|}{ Mean Neer score at entry: } \\
\hline Overall & 63.6 & 63.0 & $64 \cdot 7$ & $67 \cdot 5$ & $66 \cdot 2$ & $66 \cdot 2$ \\
\hline Pain & 13.8 & $14 \cdot 2$ & 14.8 & $15 \cdot 0$ & $14 \cdot 7$ & $15 \cdot 0$ \\
\hline Function & $22 \cdot 3$ & 22.0 & $22 \cdot 1$ & $24 \cdot 0$ & $23 \cdot 0$ & $23 \cdot 0$ \\
\hline Range of motion & $17 \cdot 5$ & $16 \cdot 8$ & $17 \cdot 8$ & 18.5 & 18.5 & $18 \cdot 2$ \\
\hline Hopkins symptom checklist & 1.6 & 1.5 & 1.6 & 1.6 & 1.6 & 1.8 \\
\hline
\end{tabular}

part of the acromion and the coracoacromial ligament. Postoperative rehabilitation was started on the first postoperative day. Physiotherapy was started within the first week. The exercises prescribed by the surgeon were performed against low resistance and repeated many times. Patients visited a physiotherapist where they lived, so several physiotherapists were engaged and somewhat different approaches used. Unrestricted activities were usually allowed after four to six weeks.

The patients who were randomised to receive supervised exercises and placebo laser treatment were all treated by the same experienced physiotherapist at the department of physical medicine and rehabilitation at this hospital. The purpose was to normalise dysfunctional neuromuscular patterns and to increase the nutrition of the collagen in the rotator cuff. ${ }^{152}$ To eliminate gravitational forces and to start the exercises the arm was suspended in a sling fixed to the roof. Relaxed repetitive movements (first rotation, then flexion-extension, and finally abduction-adduction) were performed for about an hour in a daily training session. Patients were supervised twice weekly. On the other days they followed the same exercise programme at home. Resistance was added gradually to strengthen the short shoulder rotator and the scapular stabilising muscles. The training continued for three to six months, with the supervision gradually being reduced. In addition, three lessons were given on the anatomy and function of the shoulder, pain management, and ergonometrics.

Placebo treatment was given in 12 sessions. Each consisted of exposure to a detuned soft laser and was scheduled twice weekly for six weeks.

In all treatment groups analgesics, including antiinflammatory drugs but not cortisone injections, were allowed.

\section{OUTCOME MEASURES}

Blind follow up measurements were carried out at three and six months after the first day of treatment. At follow up tests the patients wore a T-shirt to hide a possible scar from surgery. They were carefully told not to talk about their treatment.

The main outcome measure was the Neer shoulder score. ${ }^{1617}$ This has three parts: scoring of pain during the previous week by patients (verbal rating scale) ( 35 points); clinical testing of function (muscle strength, reaching ability, and stability) (30 points) and active range of motion (25 points); and an anatomical or radiological evaluation (10 points). All radiographs were assessed as normal according to the Neer criteria, so the overall scores ranged from 10 to 100 points. The active range of motion was measured bilaterally at an accuracy of $5^{\circ}$ while the patient was sitting. To eliminate interobserver influence on reliability all tests were assessed by the same physician (J I Brox).

Secondary outcome and demographic variables were assessed in a standard questionnaire, which was always completed before the consultation. Patients scored their degree of pain on activity, at rest, and at night during the previous week on nine point scales $(1=$ no pain, $9=$ worst possible). Emotional distress was rated by the Hopkins symptom checklist ( 25 items). ${ }^{18}$

\section{STATISTICAL ANALYSES}

The study was planned to detect a difference of 10 points between groups, which equals a reduction from moderate to mild pain. After a pilot study the standard deviation was estimated at 13 points. With $\alpha$ set at 0.05 (type I error) and $\beta$ at $0 \cdot 10$ (type II error) 36 patients were required for each treatment group to complete the trial.

We analysed the results according to the method of intention to treat. The Kruskal-Wallis one way analysis of variance rank test and the Mann-Whitney rank 
TABLE III-Median scores for main outcome variables and differences between active treatments with $95 \%$ confidence intervals

\begin{tabular}{|c|c|c|c|c|c|}
\hline & $\begin{array}{l}\text { Arthroscopic } \\
\text { surgery }\end{array}$ & Placebo laser & $\begin{array}{l}\text { Supervised } \\
\text { exercises }\end{array}$ & $\begin{array}{c}\text { Difference in } \\
\text { improvement } \\
\text { between active } \\
\text { treatments }\end{array}$ & $\begin{array}{l}\text { Sex adjusted } \\
\text { difference }\end{array}$ \\
\hline \multicolumn{6}{|l|}{ Overall: } \\
\hline Baseline & $64 \cdot 0$ & $65 \cdot 5$ & $67 \cdot 5$ & & \\
\hline 3 Months & $84 \cdot 0$ & $61 \cdot 0$ & $74 \cdot 0$ & $7.5(0$ to 15$)$ & $3.6(-0.2$ to 7.4$)$ \\
\hline 6 Months & $87 \cdot 0$ & $66 \cdot 0$ & $86 \cdot 0$ & $4 \cdot 0(-2$ to 11$)$ & $2.0(-1.4$ to 5.4$)$ \\
\hline \multicolumn{6}{|l|}{ Pain: } \\
\hline Baseline & $15 \cdot 0$ & $15 \cdot 0$ & $15 \cdot 0$ & & \\
\hline 3 Months & $25 \cdot 0$ & $15 \cdot 0$ & $15 \cdot 0$ & $5.0(0$ to 10$)$ & $2.8(0.5$ to 5.1$)$ \\
\hline 6 Months & $25 \cdot 0$ & $15 \cdot 0$ & $25 \cdot 0$ & $5.0(0$ to 10$)$ & $2 \cdot 1(0.1$ to 4.1$)$ \\
\hline \multicolumn{6}{|l|}{ Function: } \\
\hline Baseline & $24 \cdot 0$ & $21 \cdot 0$ & $24 \cdot 0$ & & \\
\hline 3 Months & $28 \cdot 0$ & $20 \cdot 0$ & $24 \cdot 0$ & & \\
\hline 6 Months & 28.0 & $15 \cdot 0$ & $25 \cdot 0$ & & \\
\hline \multicolumn{6}{|c|}{ Range of motion: } \\
\hline Baseline & $18 \cdot 0$ & $18 \cdot 0$ & $19 \cdot 0$ & & \\
\hline 3 Months & 21.0 & $19 \cdot 0$ & 21.5 & & \\
\hline 6 Months & $22 \cdot 0$ & $19 \cdot 0$ & $23 \cdot 0$ & & \\
\hline
\end{tabular}

TABLE IV-Median scores for secondary outcome variables and differences between active treatments with $95 \%$ confidence intervals

\begin{tabular}{|c|c|c|c|c|c|}
\hline & $\begin{array}{l}\text { Arthroscopic } \\
\text { surgery }\end{array}$ & $\begin{array}{c}\text { Supervised } \\
\text { exercises }\end{array}$ & Placebo laser & $\begin{array}{c}\text { Difference in } \\
\text { improvement } \\
\text { between active } \\
\text { treatments }\end{array}$ & $\begin{array}{l}\text { Sex adjusted } \\
\text { difference }\end{array}$ \\
\hline \multicolumn{6}{|c|}{ Pain } \\
\hline \multicolumn{6}{|l|}{ On activity: } \\
\hline Baseline & $7 \cdot 0$ & $7 \cdot 0$ & $7 \cdot 0$ & & \\
\hline 3 Months & 3.0 & $4 \cdot 0$ & $6 \cdot 0$ & $1 \cdot 0(0$ to 2$)$ & $0.4(-0.1$ to 1.0$)$ \\
\hline 6 Months & 3.0 & 3.0 & $6 \cdot 0$ & $0.0(-1$ to 1$)$ & $0.1(-0.4$ to 0.6$)$ \\
\hline \multicolumn{6}{|l|}{ At rest: } \\
\hline Baseline & $4 \cdot 0$ & $5 \cdot 0$ & $5 \cdot 0$ & & \\
\hline 3 Months & $2 \cdot 0$ & $3 \cdot 0$ & $4 \cdot 0$ & $1 \cdot 0(-0$ to 2$)$ & $0.3(-0.3$ to 1.0$)$ \\
\hline 6 Months & $2 \cdot 0$ & $2 \cdot 0$ & 4.5 & $0.0(-1$ to 1$)$ & $-0.1(-0.6$ to 0.5$)$ \\
\hline \multicolumn{6}{|l|}{ At night: } \\
\hline Baseline & $4 \cdot 0$ & $5 \cdot 0$ & $5 \cdot 0$ & & \\
\hline 3 Months & $2 \cdot 0$ & 3.0 & $5 \cdot 0$ & $1 \cdot 0(-1$ to 2$)$ & $0.4(-0.4$ to 1.1$)$ \\
\hline 6 Months & $2 \cdot 0$ & $3 \cdot 0$ & $4 \cdot 0$ & $0.0(-1$ to 2$)$ & $0.0(-0.5$ to 0.6$)$ \\
\hline \multicolumn{6}{|c|}{ Drug treatment * } \\
\hline Defined daily & & & & & \\
\hline Baseline & $0 \cdot 3$ & 0.3 & 0.4 & & \\
\hline 3 Months & $0 \cdot 3$ & 0.3 & 0.4 & & \\
\hline 6 Months & 0.2 & 0.2 & 0.2 & & \\
\hline
\end{tabular}

^ATC codes: analgesics (NO2); anxiolytics, hypnotics and sedatives (N05B and C); antidepressants (NO6A); antiinflammatory agents (MO1A); and muscle relaxants (MO3B) ${ }^{20}$

tOne defined daily dose equals $3 \mathrm{~g}$ paracetamol or $0.5 \mathrm{~g}$ naproxen.

sum test were applied to detect significant differences between groups. Non-parametric confidence intervals were calculated with the statistical computer package MINITAB. ${ }^{19}$ Multiple regression was used to measure point estimates and confidence intervals after adjustment for sex.

\section{Results}

Table I shows the reasons why some patients' treatment was different from that allocated. Additional disease was observed in four patients in the group given surgery (synovial chondromatosis, rupture of the biceps or supraspinous tendon, and rupture of both labrum articularis and supraspinous tendon). None of the patients studied had complications from their treatment.

Table II shows that the percentage of women was low in the group given surgery $(36 \%)$ compared with that given supervised exercises $(56 \%)$. The three groups did not differ in age, duration of disease, whether the dominant arm was affected, how long the patient had had sick leave, the severity of disease, and the degree of emotional stress. The mean score for the Hopkins symptom checklist was in the normal range.

Table II also shows that the placebo group was the smallest. After six months of follow up most patients in the placebo group requested another treatment Therefore an interim analysis was performed after 68 patients had completed six months of follow up. The mean change according to the Neer score was -0.3 with placebo compared with 10.8 in the exercise group and 20.2 in the surgery group. The median differences between exercises $(13.0$ (95\% confidence interval 7 to 20)) and surgery (19.5 (12 to 27)) compared with placebo were significant $(\mathrm{p}<0.001)$, and we decided to stop randomising patients to placebo treatment.

The overall improvement in the Neer score did not differ significantly when surgery and exercises were compared (table III). The median difference after six months was $4.0(-2$ to 11$)$ and $2.0(-1.4$ to 5.4$)$ after adjustment for sex. Men had best results after surgery $(6 \cdot 0(-3$ to 15$))$ and women had slightly better results after exercises $(2.0(-10$ to 13$))$. The difference between men and women was $4 \cdot 0(-2$ to 14$)$. Median pain reduction was from moderate to mild in both active treatment groups, and a significant $(p=0.03)$ difference emerged after adjustment for sex (table III). The number of patients with a good or an excellent score ( $>80$ points) was not significantly different.

The reduction in pain assessed on nine point scales was nearly equal in the two active treatment groups (table IV). Variation in the reported use of analgesics was substantial between individual patients but modest between groups.

ECONOMIC IMPLICATIONS

The average costs of treatment in Norway in 1992 were $£ 720$ for each patient operated on and $£ 390$ for each patient who had supervised exercises (table V). The stay in hospital accounted for the increased costs of surgery. Radiography cost an additional $£ 20$ in all patients. Had magnetic resonance imaging been included in the diagnostic procedures the cost would have increased by $£ 300$ for each patient.

The average length of sick leave for the six months of observation did not differ in the three groups (median 3 months). The observation period was too short to exclude possible long term benefits from active treatment in terms of reduced absence from work. Nevertheless, our findings showed that factors other than the pain in the shoulder may be important in returning to work.

\section{Discussion}

Our objective was to compare arthroscopic surgery and supervised exercises in patients with rotator cuff disease. Observed results were better after surgery, but the difference between the two treatments was neither significant nor clinically important.

The small size of the study and the large variation between patients are reflected in the wide confidence intervals, but when sex was adjusted for the confidence interval $(-1.4$ to 5.4$)$ of the difference on the main outcome variable after six months (Neer score, table III) did not include 10.0 , which we had considered to be clinically relevant before starting the study.

Rotator tendinitis, like many soft tissue lesions, offers few objective clinical variables for use in follow up studies. Our results are based on pain scores and assessment by a clinician. Verbal pain ratings were

TABLE V-Mean costs of active treatments $(\ell)^{*}$

\begin{tabular}{lcc}
\hline & $\begin{array}{c}\text { Arthroscopic } \\
\text { surgery }\end{array}$ & $\begin{array}{c}\text { Supervised } \\
\text { exercises }\end{array}$ \\
\hline $\begin{array}{l}\text { Clinical examination, treatment, and follow up } \\
\text { Hospital stay (mean 2 days) }\end{array}$ & $\begin{array}{l}170 \\
375\end{array}$ & 130 \\
Physiotherapyt & $175 \ddagger$ & $260 \$$ \\
\hline Total & 720 & 390
\end{tabular}

*For treatment in public hospitals in Norway, inclusive of costs paid by health service and patients but not costs of absence from work, consultations with general practitioners, or of radiography, other imaging techniques, or drugs.

†Administered by physiotherapist subsidised by community.

Mean (SD) number of sessions 20 (15).

$\ddagger$ Mean (SD) number of sessions 20
oMean number of sessions 30 (11). 
always scored on nine point scales in questionnaires before the clinical examination, and they may therefore have been biased. Clinically, the modest but significant difference in verbal pain ratings (table III) between surgery and the exercise regimen is hard to interpret.

The most common reason why eligible patients were not randomly allocated to the three treatments was reluctance to undergo surgery: unexpectedly, many patients dropped out from surgery. Four of them did not attend the follow up examination at six months, which might have biased our results.

There were no differences between the groups in the use of analgesics. Other possible confounding factors such as the pain associated with working, the duration of disease, and the degree of psychological distress were equally distributed in all groups at entry (table II).

Our strict criteria for inclusion were necessary to allow for the effects of the different treatments. For that reason the external validity is low with respect to the 444 patients considered for inclusion. Despite a thorough clinical examination, five patients were misclassified (figure). They all had an excellent outcome.

Pathological changes in the rotator cuff have been attributed to mechanical impingement. The role of primary impingement as the major aetiological factor has been questioned. ${ }^{72122}$ Furthermore, current techniques of subacromial decompression may not affect the structures that can enlarge the space. ${ }^{23}$ Pain inhibition after resection of nerves and postoperative rehabilitation and analgesia may also explain the improvement in the group treated surgically.

Compared with muscle, tendons have poorer nutrition and a slower turnover. ${ }^{24} 25$ The long rehabilitation period observed in both actively treated groups in our study may be attributed to an effect on slowly adapting collagen tissue.

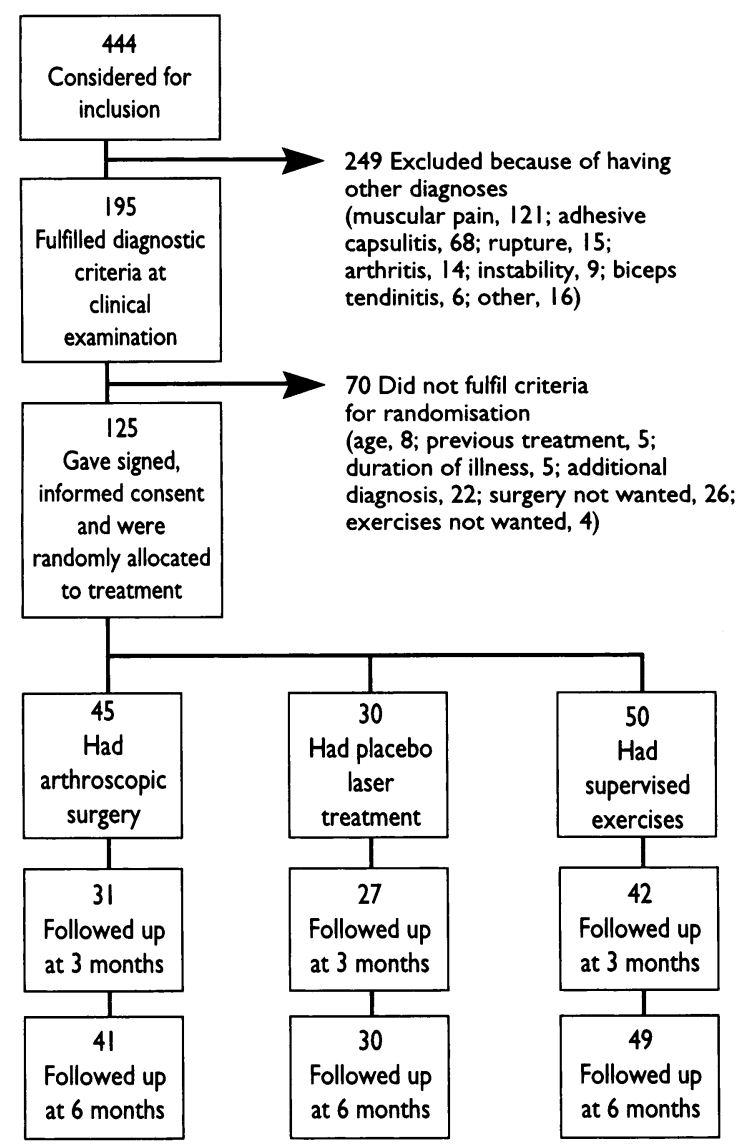

Recruitment and follow up of patients in study

\section{Clinical implications}

- Rotator cuff disease is related to overload of the short rotator muscles of the shoulder and results in pain and reduced function

- In this study patients whose condition was resistant to conventional treatment were randomised to receive arthroscopic surgery, an exercise regimen supervised by a physiotherapist, or placebo laser treatment

- After six months both active treatments were significantly better than placebo in reducing pain and improving function, but neither was significantly better than the other

- The stay in hospital accounted for the higher costs of surgery

- Rotator cuff disease may be effectively managed by a supervised exercise regimen with surgery as an alternative

We conclude that after six months of follow up both arthroscopic surgery and supervised exercises are better than placebo treatment. The difference between the two active treatments was neither clinically important nor significant, but the costs of a supervised exercise regimen were lower. Active treatment did not reduce the time of absence from work. We conclude that most cases of rotator cuff disease can be managed by a supervised exercise regimen, with arthroscopic subacromial decompression and postoperative physiotherapy as an effective alternative.

This study was supported by grants from the Norwegian Research Council. We also thank Professor Ole Sejersted, Professor Antti Alho, and Dr Erik Bautz Holter for advice, especially in designing the study; Professor Ingar Holme for statistical advice; Physiotherapist Audhild S Bøhmer for supervising the exercises and placebo laser treatments; $\mathrm{Dr}$ Gisle Uppheim and Dr Erling Gjengedal for performing arthroscopic surgery; Dr Erik Skuterud for advice on diagnoses and on handling patients; the Norwegian Institute of Sports Medicine; Ms Anne Lise Vengsholt and Ms Marianne Bjørnvand for secretarial and administrative help; Ms Unni Hauland, Ms Marit Brevik, and Mr Per Ludvigsen; and all the patients who made this study possible.

1 Bergenudd $\mathrm{H}$, Lindegärde F, Nilsson B, Peterson CJ. Shoulder pain in middle age. Clin Orthop 1988;231:234-8.

2 Bye A. Belastningslidelser hos ansatte i bygg- og anleggsbransjen. Tidsskr Nor Laegeforen 1991;111:337-40.

3 Herberts P, Kadefors R, Andersson G, Petrsen I. Shoulder pain in industry: an epidemiological study on welders. Acta Orthop Scand 1981;52:229-306.

4 Lehman RC. Shoulder pain in the competitive tennis player. Clin Sports Med 1988;7:309-27.

5 Lo Y, Hsu Y, Chan K. Epidemiology of shoulder impingement in upper arm sports events. Brf Sports Med 1990;24:173-7.

6 Järvholm U, Palmerud G, Herberts P, Høgfors C, Kadefors R. Intramuscular pressure and electromyography in the supraspinatus muscle at shoulder abduction. Clin Orthop 1989;245:102-9.

7 Nirschl RP. Rotator cuff tendinitis. Instructional Course Lectures 1987;41:43945.

8 Fu FH, Harner C, Klein H. Shoulder impingement syndrome. Clin Orhop 1991;269:162-73.

9.er CS. Impingement lesions. Clin Orthop 1983;173:71-7.

10 O'Reily D, Bernstein RM. Shoulder pain in the elderly. $B M 7$ 1990;301:503-4.

11 Chard MD, Satelle LM, Hazleman BL. The long-term outcome of rotator cuff tendinitis-a review study. Br 7 Rheumatol 1988;27:385-9.

12 Neer CS. Anterior acromionplasty for the chronic impingement syndrome in the shoulder. $f$ Bone foint Surg [Am] 1972;54:41-50.

13 Post M, Cohen J. Impingement syndrome. Clin Orthop 1986;207:126-32.

14 Ellman H. Arthroscopic subacromial decompression: analysis of one- to threeyear results. Arthroscopy 1987;3:173-81.

15 Cyriax J. Textbook of orthopaedic medicine. Vol I. London: Bailliere Tindall, 1982.

15a Bøhmer AS. Trening ved kroniske degenerative skulderlidelser. Fysioterapeuten 1984;51:192-7.

Neer CS. Displaced proximal humeral fractures. I Bone foint Surg [Am] 1970;52:1090-103.

17 Bjorkenheim J-M, Paavolainen P, Ahovuo J, Slătis P. Surgical repair of the rotator cuff and surrounding tissues. Clin Orthop 1988;236:148-53.

18 Derogatis LR, Lipman RS, Rickels K, Uhlenhut EH, Cori L. The Hopkins serogatis LR, Lipman RS, Rickels K, Uhlenhut EH, Cori L. The Hopkins
symptom checklist (HSCL): A self-report inventory. Behav Sci 1974;19:115.

19 Ryan BF, Joiner BL, Ryan TA. Minitab handbook. 2nd ed. Boston: Duxbury Press, 1985. 
20 WHO Collaboration for Drug Statistics Methodology. Guidelines for ATC classification. Oslo: World Health Organisation, 1990.

21 Hardy D, Vogler III J, White R. The shoulder impingement syndrome: prevalence of radiographic findings and correlation with response to therapy. I Radiol 1986;147:557-61.

22 Ozaki J, Fujimoto S, Nakagawa Y, Masuhara K, Tamai S. Tears of the rotator cuff of the shoulder associated with pathological changes in the acromion. f Bone foint Surg [Am] 1988;70:1224-30.
23 Edelson JG, Taitz C. Anatomy of the coraco-acromial arch. $f$ Bone foint Surg [Br] 1992;74:589-94.

24 Tipton CM, Matthes RD, Maynard JA, Carey RA. The influence of physical activity on ligaments and tendons. Med Sci Sports Exerc 1975;7:165-75.

25 Woo SLY, Gomez MA, Woo YK, Akeson WH. Mechanical properties of tendon and ligaments. Biorheology 1982;19:397-408.

(Accepted 12 August 1993)

\title{
Cost analysis of early discharge after hip fracture
}

\author{
William Hollingworth, Chris Todd, Martyn Parker, Jennifer A Roberts, Rhys Williams
}

\begin{abstract}
Objective-To ascertain the economic impact of an early discharge scheme for hip fracture patients.

Design-Population based study comparing costs of care for patients who had "hospital at home" as an option for rehabilitation and those who had no early discharge service available in their area of residence.

Setting-District hospital orthopaedic and rehabilitation wards and community hospital at home scheme.
\end{abstract}

Patients-1104 consecutively admitted patients with fractured neck of femur. 24 patients from outside the district were excluded.

Main outcome measures-Cost per patient episode and number of bed days spent in hospital.

Results-Patients with the hospital at home option spent significantly less time as inpatients (mean of $32.5 v 41.7$ days; $p<0.001$ ). Those patients who were discharged early spent a mean of 11.5 days under hospital at home care. The total direct cost to the health service was significantly less for those patients with access to early discharge than those with no early discharge option $(£ 4884 v £ £ 5606$; $\mathrm{p}=0.048$ ).

Conclusions-About $40 \%$ of patients with fractured neck of femur are suitable for early discharge to a scheme such as hospital at home. The availability of such a scheme leads to lower direct costs of rehabilitative care despite higher readmission costs. These savings accrue largely from shorter stays in orthopaedic and geriatric wards.

Health Services Research Group, Institute of Public Health, University of Cambridge, Cambridge William Hollingworth, research assistant

Chris Todd, senior research associate

Rhys Williams, university

lecturer

\section{Peterborough District}

Hospital, Peterborough

Martyn Parker, research

registrar

\section{Department of Public}

Health and Policy, London

School of Hygiene and

Tropical Medicine,

London

Jennifer A Roberts, senior

lecturer

Correspondence to:

Mr Hollingworth, Health

Services Research Group, Institute of Public Health, University of Cambridge, University Forvie Site, Robinson Way, Cambridge CB2 2SR. out in the patient's home ${ }^{7}$ The surgical treatme hip fracture patients in Peterborough has been described in detail elsewhere. ${ }^{89}$ Briefly, it is based on the principle that, whenever practical, patients should be operated on immediately after admission and mobilised shortly afterwards. Once the postoperative recovery has begun some patients are able to be discharged to the hospital at home scheme. The scheme provides care from trained nurses, nursing auxiliaries, physiotherapists, and occupational therapists in the patient's home for up to 24 hours a day under the medical supervision of the general practitioner. The service also musters social services, meals on wheels, and home helps. The amount of care is tailored to meet the patient's needs, and the scheme is generally continued for up to two weeks before other community services take over.

Previous studies of the early discharge of hip fracture patients showed no significant difference in mortality between the hospital at home group and a comparison group over a 40 month period $^{10}$ and equal return of functional ability at three months. ${ }^{11}$ This paper is a cost analysis comparing patients who had access to hospital at home services as an option for rehabilitation with patients who had no such early discharge scheme available. We focused on direct costs to the NHS and the impact of hospital at home on bed use in the orthopaedic and rehabilitation wards.

\section{Patients and methods}

From 1 January 1987 until 31 December 1991, 1104 patients were admitted to Peterborough District Hospital with a fractured neck of femur. Twenty four of these lived outside the hospital's catchment area and were excluded from the analysis. The remaining 1080 patients were followed up. Information was recorded on variables such as age; functional, ${ }^{12}$ social, ${ }^{13}$ and mental ${ }^{14}$ status; type of treatment received; and length of stay under NHS care.

The hospital at home scheme is currently available only to patients who come from Peterborough city and the villages to the south of Peterborough. Patients resident in Stamford and villages to the north of Peterborough have no early home rehabilitation scheme available. The patients were divided into two groups on this basis.

We used the cost apportionment approach. ${ }^{1516}$ The cost of treatment is broken down into its various components: hotel costs, theatre costs, medical costs, ward costs, overheads, and other treatment expenses. A distinction is then made as to which components vary with length of stay and are therefore the variable costs affected by early discharge.

The resources used by each hip fracture patient were assessed by three methods. Where possible, information on actual individual use of resources-for example, the number of minutes spent in the operating theatre and the cost of the implant each patient received-was used. The nursing time of hospital at home staff and travel costs could also be estimated directly as they are routinely recorded. The large numbers of patients under study meant that detailed individual information could not be recorded for all patients in all aspects of care. For drugs, laboratory 